\title{
The Effects of Lornoxicam on Neuroprotection Following Diffuse Traumatic Brain Injury in Rats
}

\author{
Diffii: Travmatik Beyin Hasarnda Ratlarda Lornoksikamm \\ Nöroprotektif Etkileri
}

\author{
Ismet TOPCU ${ }^{1}$, Seda VATANSEVER ${ }^{2}$, Eda BAYRAM ${ }^{1}$, Ahmet VAR ${ }^{3}$, Ismail CETIN ${ }^{1}$, Melek CIVI ${ }^{1}$ \\ ${ }^{1}$ Celal Bayar University, Faculty of Medicine, Department of Anesthesiology and Intensive Care, Manisa, Turkey \\ ${ }^{2}$ Celal Bayar University, Faculty of Medicine, Department of Histology and Embryology, Manisa, Turkey \\ ${ }^{3}$ Celal Bayar University, Faculty of Medicine, Department of Biochemistry, Manisa, Turkey
}

Corresponding Author: Ismet TOPCU / E-mail: topcuismet@yahoo.com

\begin{abstract}
AIM: In this study, the effects of lornoxicam on the prevention of secondary brain injury via the apoptotic pathway were studied in a rat model of head injury.

MATERIAL and METHODS: Thirty adult male Wistar albino rats were anesthetized, and experimental closed head trauma was induced by allowing a $450 \mathrm{~g}$ weight to fall two meters onto a metallic disk fixed to the intact skull. After head injury, the rats were randomly divided into two groups: Group I ( $n=15)$ rats were administered $2 \mathrm{~mL}$ saline intraperitoneally (controls); Group II $(n=15)$ rats were administered $2 \mathrm{~mL} 1.3$ $\mathrm{mg} \mathrm{kg}^{-1}$ lornoxicam intraperitoneally. Brain tissue samples were divided into two pieces by interhemispheric incision for biochemical and histological analysis.

RESULTS: TUNEL positivity was seen in neuroglia cells of the brain cortex in both groups. While the immunoreactivities of caspase 8, 9 and Fas/ Fas ligand were similar in both groups, the immunoreactivity of caspase 3 was greater in Group I than Group II. MDA was significantly lower in Group II than in Group I $(\mathrm{p}<0.05)$. The decrease in SOD level was higher in Group I than Group II.
\end{abstract}

CONCLUSION: Lornoxicam did not prevent apoptosis in this rat model of brain trauma but causes a decrease.

KEYWORDS: Traumatic brain injury, Lornoxicam, Apoptosis, Neuroprotection, Rats

öz

AMAÇ: Bu çalışmada, lornoksikamın sekonder beyin hasarını önlemede, kafa travmalı bir rat modelinde apoptotik yollar aracılı etkileri araştırıldı. YÖNTEM ve GEREÇLER: Otuz erişkin Wistar albino rata anestezi uygulaması sonrası kafatası üzerine konan bir metal disk üzerine 2 metreden $450 \mathrm{~g}$ ağırlık düşürülerek deneysel kapalı kafa travması oluşturuldu. Travma sonrası ratlar randomize olarak 2 gruba ayrıldı; Grup l'e ( $\mathrm{n}=15$ ) intraperitoneal yolla $2 \mathrm{~mL}$ salin, Grup II $(\mathrm{n}=15)$ intraperitoneal yolla $2 \mathrm{~mL} 1.3 \mathrm{mg} \mathrm{kg}^{-1}$ lornoksikam verildi. Beyin dokuları biyokimyasal ve histolojik incelemeler için interhemisferik kesi ile ikiye ayrıldı.

BULGULAR: TUNEL pozitifliği her iki grupta beyin korteks nöroglia hücrelerinde görüldü. Her iki grupta kaspaz 8, 9 ve Fas/Fas ligand immünoreaktivitesi normalken, kaspaz 3 immünoreaktivitesi Grup I'de Grup II'den daha yüksekti. MDA Grup II'de Grup I'den daha düşüktü. SOD düzeyindeki azalma Grup I'de, Grup II'den daha fazlaydı.

SONUÇ: Lornoksikam bu beyin travması rat modelimizde apoptozisi önlememiş ancak bir azalma sağlamıştır.

ANAHTAR SÖZCÜKLER: Beyin hasarı, Kapalı kafa travması, Lornoksikam, Apoptozis, Ratlar

\section{INTRODUCTION}

The cranium is a commonly injured body part in multitrauma patients. Brain injury has been found in approximately $85 \%$ of traffic accident victims who die from their wounds (1). The mortality rate in severe head trauma ranges from 27 to $39 \%$ (17). As primary injuries to brain tissue in head trauma cannot be prevented, treatments are oriented to prevent or eliminate secondary brain injuries caused by biochemical or physiological events arising in the subsequent hours or days following the trauma. The aim of treatment is to limit the injury process and thus prevent secondary brain injury.
Death of neuronal cells in the central nervous system occurs in two phases after traumatic brain injury (TBI). The early phase is death as a result of neuronal cell membrane disruption, irreversible metabolic impairments and/or excitotoxic necrosis immediately after the mechanical trauma (14). The later phase of neuronal death occurs from apoptosis (programmed cell death) (9), within a time frame in which the patient's clinical condition may respond to targeted therapies (16).

In the early phase of secondary injury, lactic acid accumulates as a result of anaerobic glycolysis, causing edema due to an increase in membrane permeability $(20,25)$. In the 
later phase, excitatory neurotransmitters are secreted and voltage-gated sodium and calcium channels are activated. It activates enzymes which increase intracellular free fatty acids and free radicals such as calcium lipid peroxidase, protease, and phospholipase. These then cause degeneration in cell membrane and venous structures and apoptosis ensues $(15,18)$.

Cyclooxygenase-2 (COX-2) is an important inflammatory mediator that converts arachidonic acid in the injured membrane into vasoactive prostaglandins, thus causing the creation of reactive oxygen radicals $(6,12)$. After traumatic brain injury, these radicals injure neuronal membranes, white matter, and the tight junctions forming the bloodbrain barrier (34). Peroxidative reactions may actively be involved in progressive vascular injury, which then impairs autoregulation and consequently results in arterial vasospasm and thrombosis. Thus COX-2 products play an important role in secondary clinical problems such as increased intracranial pressure, vasospasm, and ischemia. COX-2 inhibitors have been shown to be cerebroprotective in animal models of head trauma (34). The increase in levels of COX-2 in the brain is related to the central inflammatory response. These occurrences also contribute to secondary post-traumatic brain injury.

Lornoxicam is a non-steroidal anti-inflammatory drug (NSAID) with effective analgesic and anti-inflammatory properties. It has balanced COX-1/COX-2 inhibitory effects and is well tolerated $(3,27)$. In this study, we examined the neuroprotective effects of lornoxicam in preventing apoptosis in a rat model of traumatic brain injury.

\section{METHODS}

\section{Animals}

The Declaration of Helsinki recommendations and internationally and locally accepted principles were followed for the care and use of the animals in this study. Committee on the Human Care of Laboratory Animals of Faculty of Medicine certified this study. Under environmental conditions (temperature $22^{\circ} \mathrm{C}$, humidity $65 \%$, and light-dark cycles $12 \mathrm{~h}: 12$ h), 30 adult male Wistar albino rats which weigh 220-259 g were kept at least 4 days. Except the last 20-30 min before the beginning of the experiment which the rats had access to water, they fasted for 18 hours. All experiments were initiated between 10 and $11 \mathrm{am}$.

Diffuse closed head injury was performed on the rats after anesthesia with a bolus of IP pentothal (30 $\mathrm{mg} \mathrm{kg}^{-1}$ ) by the Marmarou method: a $450 \mathrm{~g}$ weight was dropped from $2 \mathrm{~m}$ onto a metal disc attached to the intact skull of the anesthetized rat (19). After trauma the rats were randomly divided into control and lornoxicam groups: Group I (controls, $\mathrm{n}=15$ ) rats were given $2 \mathrm{~mL}$ of saline $\mathrm{IP}$, and Group II rats (lornoxicam, $\mathrm{n}=15$ ) were given $2 \mathrm{~mL}$ of lornoxicam IP (1.3 $\mathrm{mg} \mathrm{kg}^{-1}$ ). The rats were sacrificed by cervical dislocation 24 $\mathrm{h}$ after drug administration and brain tissues were removed atraumatically. Brain tissue samples were divided into two pieces by interhemispheric incision.

\section{Histological Evaluation}

\section{Light Microscopy}

From all groups, brain tissue was collected after cervical dislocation and was fixed in $10 \%$ formalin solution for $24 \mathrm{~h}$. It was embedded in paraffin blocks after processing using routine protocols. Five micron sections were taken using microtome (RM2135 ${ }^{\circledR}$, Leica, Vienna, Austria). Sections were divided into three samples to be used for histochemical, TUNEL, and immunohistochemical assays.

\section{HISTOCHEMICAL ANALYSIS}

For histochemical analysis, they were stained with hematoxylin-eosin using routine protocol; however, for immunohistochemical analysis, sections were deparaffinized at $60^{\circ} \mathrm{C}$ overnight and xylene for $30 \mathrm{~min}$. Sections were first rehydrated in a series of baths with decreasing amounts of ethanol. After washing with distilled water and then phosphate-buffered saline (PBS) for $10 \mathrm{~min}$ each, they were incubated with $2 \%$ tyripsin at $37^{\circ} \mathrm{C}$ for $15 \mathrm{~min}$. Sections were marked with a Dako pen (Dako, Glostrup, Denmark) and were added $3 \% \mathrm{H} 2 \mathrm{O} 2$ solution for $15 \mathrm{~min}$ to inhibit endogenous peroxidase activity. The primary antibodies anticaspase-3 (NB 600-1235, Novus Biologicals, Littleton, USA), anti- caspase-8 (RB 1200-P, Neomarkers, Fremont, USA), anticaspase-9 (NB 100-56118, Novus Biologicals, Littleton, USA) and anti-Fas/Fas ligand (DB042, Delta Biolabs, Gilroy, USA) were applied in a dilution of 1:100 at $4^{\circ} \mathrm{C}$ overnight. After washing with PBS three times, the secondary antibodies biotinylated IgG (supplied ready to use) and streptavidin-peroxidase conjugate (supplied ready to use) were incubated for 30 min. To detect immunolabelling, $50 \mu \mathrm{L}$ of diaminobenzidine solution (DAB, 00-2020, Invitrogen, Camarillo, USA) was added to each section and observed after $5 \mathrm{~min}$. They were washed with distilled and water and counterstained with Mayer's hematoxylin (02274390059, J.T.Barker, Deventer, the Netherlands) for $5 \mathrm{~min}$. After washing with distilled water one more time, sections were dehydrated using $80 \%$ and $95 \%$ ethanol, dipped into xylene and covered with mounting media (H701, CC/ Mount, Universal Phosphatase Kit, Diagnostic BioSystems, Pleasanton, USA). As long as the same treatment was received by the negative control sections, instead of the primary antibodies, they were incubated with rabbit IgG or mouse lgG. All specimens were then evaluated under a light microscope (Olympus BX40, Tokyo, Japan).

\section{Detection of the Apoptotic Cell Death in Situ Using the TUNEL Method}

TUNEL (terminal deoxynucleotidyl transferase-mediated dUTP nick end-labeled) assay was used in situ cell death detection (G7130 Promega). After deparaffinization and dehyration of sections, they were incubated with $20 \mathrm{mg}$ $\mathrm{ml}-1$ proteinase $\mathrm{K}$ for $10 \mathrm{~min}$. Sections were washed with distilled water and incubated with $3 \%$ hydrogen peroxide for $5 \mathrm{~min}$ to inhibit endogenous peroxidase activity. Following the incubation of the sections with an equilibration buffer for $10-15 \mathrm{~s}$, in a humidified atmosphere at $37^{\circ} \mathrm{C}$, they were soaked 
in Tdt enzyme for $60 \mathrm{~min}$. They were dipped into a stop/wash buffer at room temperature for $10 \mathrm{~min}$ and incubated in antistreptavidin peroxidase solution at a 1:500 dilution in PBS for $45 \mathrm{~min}$. TUNEL-stained cells were detected using DAB/H2O2 solution, the nuclei of cells were counterstained with Mayer's hematoxylin and mounted as described above.

\section{Evaluation of Sections}

All histochemical, immunohistochemical and TUNEL sections were evaluated using a light microscope (Olympus BX40, Tokyo, Japan). Two observers blinded to the experimental conditions graded the intensity of immunolabelling such as weak $(+)$, moderate $(++)$, and strong $(+++)$. Each section was counted for 100 TUNEL-positive cells from randomly chosen fields. The percentage of apoptotic cells (labelled brown) was calculated. Cells in areas with necrosis, poor morphology, or at the margins of sections were excluded from this study.

\section{Biochemical Evaluation}

\section{Malondialdehyde (MDA)}

MDA was determined by the spectrophotometry (Shimadzu UV-1201V, Kyoto, Japan) method (22,37). 1,1,3,3-tetraethoxypropane was used for an external standard curve. MDA levels were expressed as $\mathrm{nmol} / \mathrm{g}$ tissue protein.

\section{GSH-Px}

Glutathione peroxidase (GSH-Px) catalyzes the reduction of deleterious peroxides such as lipid peroxide and $\mathrm{H}_{2} \mathrm{O}_{2}$. During this reduction, reduced glutathione $(\mathrm{GSH})$ is converted to oxide glutathione (GSSG). In the presence of $\mathrm{H}_{2} \mathrm{O}_{2}$, GSSG produced by GSH-Px is transformed into GSH by glutathione reductase and NADPH. GSH-Px activity was assessed during oxidation of NADPH to NADP by measuring absorbance variation at $340 \mathrm{~nm}(24,37)$. Results were expressed as IU per mg tissue protein.

\section{Superoxide Dismutase (SOD)}

Superoxide formation via the xanthine/xanthine oxidase system depends on the reduction of nitroblue tetrazolium (NBT) (37). SOD activity measured according to the method of Sun et al. (35). Superoxide radicals form colored formazan compounds by reducing NBT, with a maximum absorbance at a wavelength of $560 \mathrm{~nm}$. This reduction is maximal in the absence of this enzyme, with formation of a significant bluepurple color. NBT reduction decreases in the presence of SOD; the formation of the colored formazan is inhibited relative to the activity and amount of the enzyme. Results were expressed as units/g of tissue protein.

\section{Statistical Analysis}

Statistical analyses were performed using SPSS for Windows ${ }^{\circledast}$ v14.0 (SPSS, Inc., Chicago, USA). The percentage of apoptotic cells was expressed as mean $\pm S D$. The apoptosis index, MDA, GSHPx, and SOD values were compared using a one-way ANOVA test. The Mann-Whitney $U$ test was used for the comparison of dual groups. Results with a $p$ value of less than 0.05 were considered to be statistically significant.

\section{RESULTS}

\section{Histochemical}

On evalation of $\mathrm{H}$-E stained specimens, layers of the cerebrum (cortex and medulla) were detected clearly in Group I; in addition, some cytoplasm of pyramidal cells in the cerebral cortex stained eosinophilic (more so than in Group II). Some neurons in both Groups I and II had picnotic nuclei. Also in both groups, occasional clumping of microglia and fusiformshaped microglia were observed. Oligodentrocytes with perinuclear space were seen, especially in Group I (Figure 1AD).

\section{TUNEL}

On the TUNEL assay, apoptotic cells with picnotic nuclei and apoptotic bodies were detected. More TUNEL positive cells were detected in Group I $(20.4 \pm 0.9)$ than in Group II (15.7 \pm 0.6$)$ $(\mathrm{p}<0.002$, Table I, Figure 2A,B).

\section{Immunohistochemical}

The evaluation of apoptotic pathway molecules after brain injury, the caspase-3, $-8,-9$ and Fas/FasL were evaluated with immunoperoxidase technique. While the immunoreactivity of caspase- 9 was weak in both groups, the immunoreactivities of caspase-3, caspase-8 and FASL were less in Group II than in Group I. In Group I, the immunoreactivities of caspase-8 and Fas/Fas ligand were weak, while that of caspase-3 was moderate. The weak immunoreactivities of caspase-3 and caspase- 9 and rare immunoreactivities of caspase- 8 and Fas/Fas ligand were observed in treatment group. All immunoreactivities were detected in TUNEL positive cells. Caspase-3 immunoreactivity was greater in Group I than in Group II (Table I, Figure 3A-H).

\section{Biochemical}

MDA and SOD activities were less in Group II than in Group I $(p<0.05)$. GSH-Px values in the two groups were not significantly different from each other (Table II).

\section{DISCUSSION}

Lornoxicam does not prevent but decrease apoptosis, it was also found to decrease reactive oxygen species in this model of blunt traumatic brain injury. Thus lornoxicam decreased markers of processes thought to be important in secondary brain injury.

The initiation of apoptosis originates from two different but related signals. One of these signals is the extrinsic or receptor-initiated pathway, and the other is the intrinsic or mitochondrial pathway. The two pathways both activate caspase and interact with each other at several different levels (30). Numerous stimuli can trigger apoptosis, including withdrawal of essential growth factors or hormones or engagement of various receptor/ligands including Fas/Fas ligand and tumor necrosis factor (TNF) / TNF receptor $(21,32)$. Apoptosis is also regulated by several additional genes, which potentiate ( $\mathrm{p53}$; Bax; $\mathrm{c}-\mathrm{myc}$ ) or inhibit ( $\mathrm{Bcl}-2 ; \mathrm{Bcl}-\mathrm{xL}$; sentrin) programmed cell death $(23,28)$. In addition, the signaling 
Table I: Percentage of Apoptotic Cells Determined by the TUNEL (terminal Deoxynucleotidyl Transferase-Mediated dUTP Nick EndLabeled) Method and Immunohistochemical Activities in Controls and Lornoxicam-Treated Rats

\begin{tabular}{|c|c|c|}
\hline & $\begin{array}{l}\text { Group I (control) } \\
\qquad n=15\end{array}$ & $\begin{array}{l}\text { Group II (lornoxicam) } \\
\qquad n=15\end{array}$ \\
\hline Apoptosis (TUNEL) (\%) & $20.4 \pm 0.9$ & $15.7 \pm 0.6^{*}$ \\
\hline Caspase-3 & ++ & + \\
\hline Caspase-8 & + & $-/+$ \\
\hline Caspase-9 & + & + \\
\hline Fas ligand & + & $-/+$ \\
\hline
\end{tabular}

* $p<0.0002$ when compared with Groups I.

Table II: Tissue Malondialdehyde (MDA), Glutathione Peroxidase (GSH-Px) and Superoxide Dismutase (SOD) Levels in Controls and Lornoxicam-Treated Rats

\begin{tabular}{l|c|c} 
& Group I (control) & Group II (lornoxicam) \\
& $n=15$ \\
MDA (nmol/mg protein) & $1.32 \pm 1.60$ & $0.47 \pm 0.19$ \\
GSH-Px (IU/g protein) & $8.9 \pm 0.8$ & $7.7 \pm 2.6$ \\
SOD $(\mu /$ g protein) & $1.7 \pm 0.8$ & $4.7 \pm 4^{*}$
\end{tabular}

* $p<0.05$ when compared with Groups I.

pathway leading to apoptosis involves the sequential activation of cysteine proteases known as caspases. The caspase cascade involved in apoptosis includes both initiator caspases and effector caspases (36). Caspases-2, -8, -10, -12 and caspases-3, $-6,-7$ have been described as initiator and effector caspases, respectively. As a result of these processes, apoptosis occurs, characterized by DNA fragmentation and chromatin condensation; this differs from necrosis, which is characterized by ruptured cell membranes and swollen nuclei.

Active caspase-3, the cellular marker of apoptosis, has been detected in neurons, astrocytes and oligodentrocytes after traumatic brain injury (4). In vivo studies have found that COX-2 inhibitors decrease the activation of caspase-3 in hippocampal neurons and inflammatory cells $(5,29)$. These findings are similar to ours, namely that a decrease in apoptosis was detected histopathologically in rats given lornoxicam.

Neuroinflammation is closely related to the overproduction of reactive oxygen species (ROS) that causes many neuropathologies. Free radicals damage cell contents such as lipids, protein and DNA. Antioxidant and anti-inflammatory drugs have been comprehensively studied in neurotrauma models (8,31). Cyclooxygenase inhibitors act as neuroprotective agents by decreasing the formation of prostanoid and free radicals or by directing arachidonic acid metabolism to different metabolic ways $(7,11,34)$.

Oxidative stress and lipid peroxidation (LPO) increase in brain tissue after head trauma $(26,38)$. Pratico et al. $(26)$, in their research of the local and systemic effects of LPO after experimental head trauma, found increased levels of MDA, the final product of LPO. Üstün et al. (38) found that MDA levels were higher in contused tissue than in non-contused tissue in an animal model of brain injury induced by the free fall of a weight. We also found that TBI causes an increase in MDA levels inducing the peroxidation of membrane lipids. This increase in lipid peroxidation accompanies a decrease in glutathione levels. These two parameters are the important parameters of alternative oxidant pathways which can be reversed with lornoxicam. In our study, the higher levels of superoxide dismutase activity induced by TBI decreased with lornoxicam treatment. Other COX-2 inhibitors besides lornoxicam have also been reported to have antioxidant effects, in addition to their anti-inflammatory actions $(2,8)$.

Gopez et al. (7) have showed that functional recovery of neurological and behavioral performances is achieved 3 days after the injury with COX-2 inhibitor treatment. They showed that the immune reaction peaks between 24-72 hours after injury and the neuroprotective effect of treatment with COX-2 inhibitors begins 6 hours after injury (7). Various researchers have observed increased motor performance after neurotrauma and ischemia with COX-2 inhibitors in animal models $(5,8)$. In our study, animals were sacrificed 24 hours after trauma, which allowed time for the effects of COX2 inhibition to occur.

While COX-1 is structurally produced in normal tissues, COX-2 is produced as a response to inflammation and induces the synthesis of inflammatory mediators $(13,39)$. COX-2 inhibition has antioxidant as well as anti-inflammatory effects $(13,39)$. Several authors have evaluated the effects of COX inhibitors in traumatic brain injury $(7,10,34)$ and found no protective effect in some studies (10), whereas others have found neuronal 


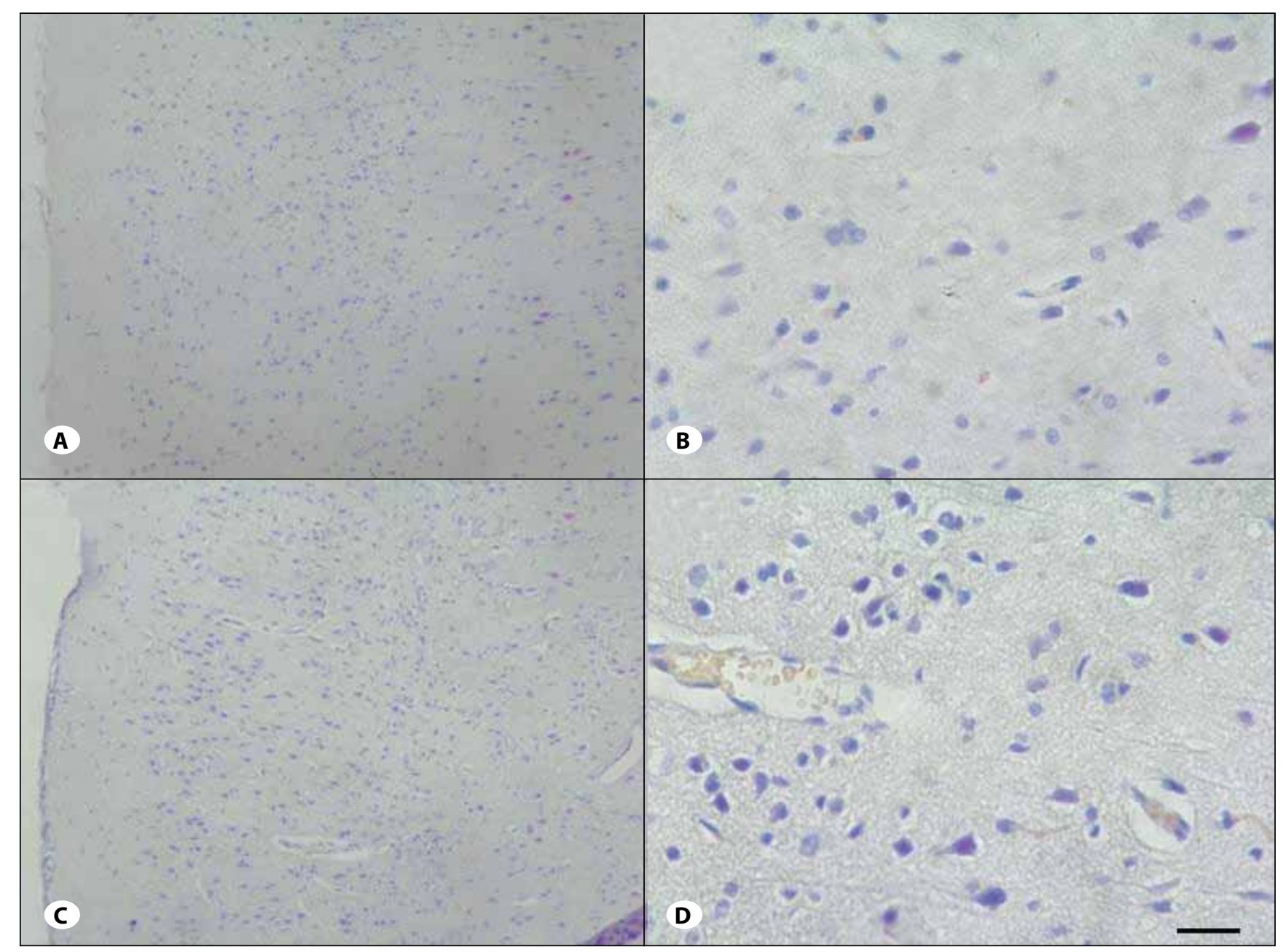

Figure 1: Histochemical observation of brain sample from Group I (A,B) and Group II (C, D). H-E, Scale bars: $25 \mu \mathrm{m}$.

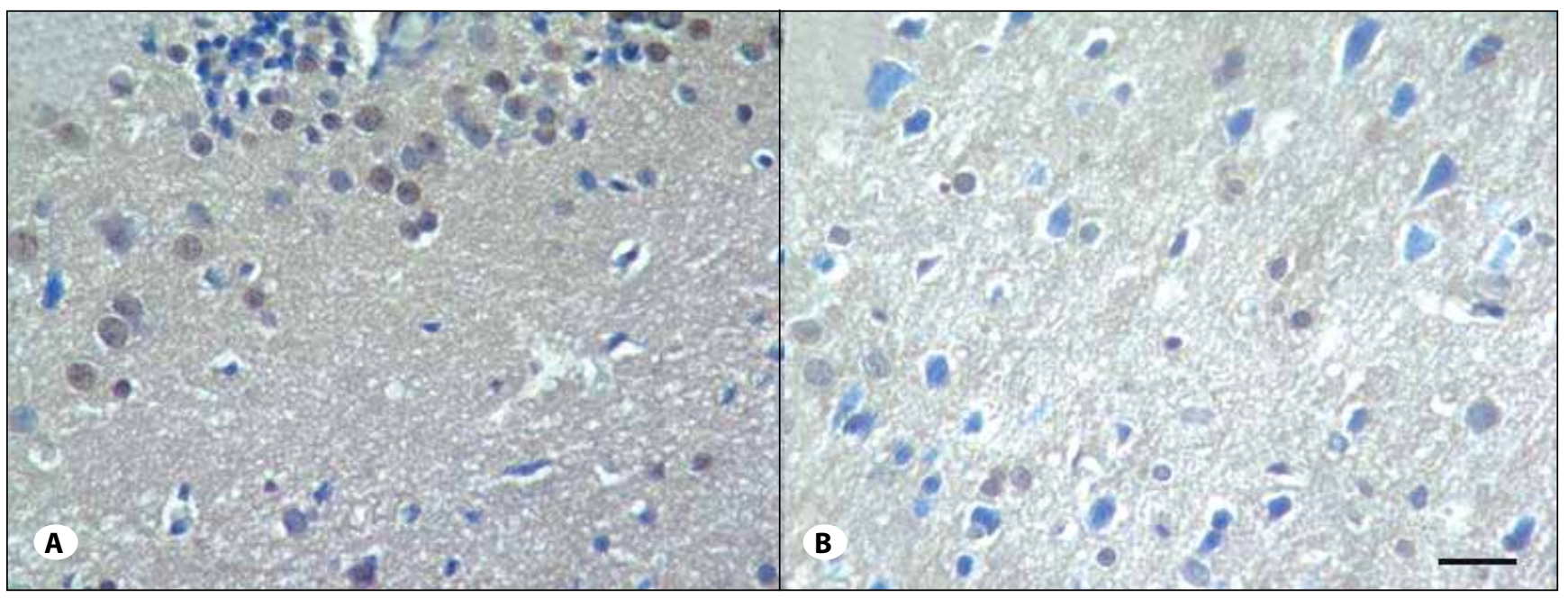

Figure 2: TUNEL staining of brain samples from Group I (A) and Group II (B). Scale bar: $25 \mu \mathrm{m}$. 


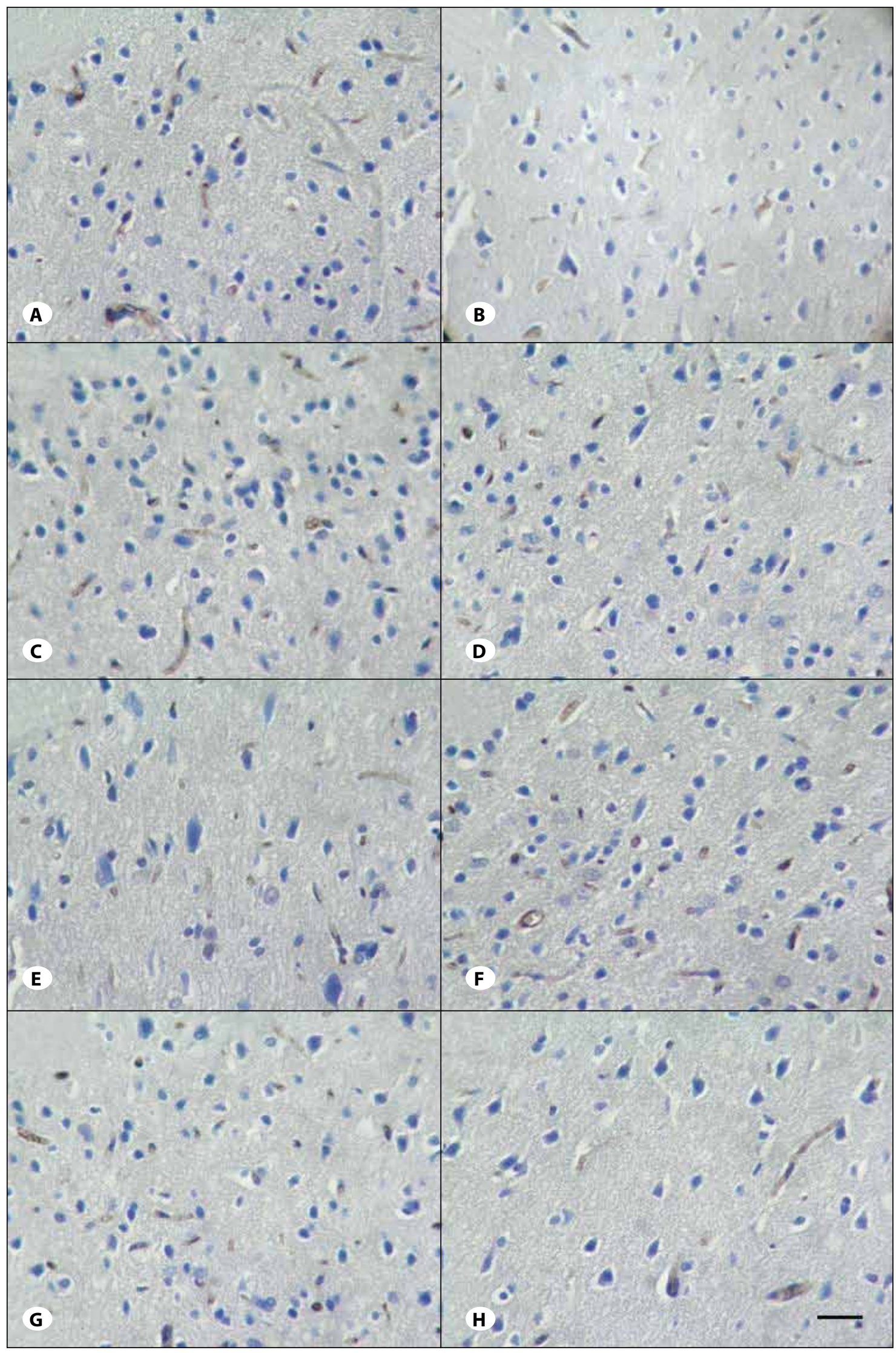

Figure 3:

(A, B) The

distributions of caspase 3,

(C, D) caspase-8, (E, F) caspase-9 and (G, H) Fas/ Fas ligand immunolabelling in brain samples from Group I $(\mathbf{A}, \mathbf{C}, \mathbf{E}, \mathbf{G})$ and Group II (B, D, E, H). Scale bar: 25 $\mu \mathrm{m}$. 
recovery in both in-vivo and in-vitro models $(7,33)$. Hickey et al. (10) proposed that the conflicting results of COX inhibitors in these studies may derive from the differences in trauma models and treatment protocols. Although lornoxicam is an effective COX-2 inhibitor which can be given orally or parenterally, to date this study is the first to use lornoxicam in a model of TBI.

In this animal model of TBI, as measured with biochemical and immunochemical indicators, lornoxicam decreased oxygen free radical and lipid peroxidation activities which are thought to play an important role in secondary brain injury. On histologic evaluation, lornoxicam did not prevent apoptosis but causes a decrease.

\section{REFERENCES}

1. Adams JH, Doyle D, Ford I, Gennarelli TA, Graham DI, McLellan DR: Diffuse axonal injury in head injury: Definition, diagnosis and grading. Histopathology 15:49-59, 1989

2. Agha AM, El-Khatib AS, Al-Zuhair H: Modulation of oxidant status by meloxicam in experimentally induced arthritis. Pharmacol Res 40: 385-392, 1999

3. Balfour JA, Fitton A, Barradell LB: Lornoxicam. A review of its pharmacology and therapeutic potential in the management of painful and inflammatory conditions. Drugs 51 (4):639-657, 1996

4. Beer R, Franz G, Srinivasan A, Hayes RL, Pike BR, Newcomb JK, Zhao X, Schmutzhard E, Poewe W, Kampfl A: Temporal profile and cell subtype distribution of activated caspase-3 following experimental traumatic brain injury. J Neurochem 75:1264-1273, 2000

5. Candelario-Jalil E, Alvarez D, Castaneda JM, Al-Dalain SM, Martínez-Sánchez G, Merino N, León OS: The highly selective cyclooxygenase-2 inhibitor DFU is neuroprotective when given several hours after transient cerebral ischemia in gerbils. Brain Res 927:212-215, 2002

6. Ellis EF, Police RJ, Rice LY, Grabeel M, Holt S: Increased plasma PGE2, 6-keto-PGF1 alpha, and 12-HETE levels following experimental concussive brain injury. J Neurotrauma 6: 31-37, 1989

7. Gopez JJ, Yue $H$, Vasudevan R, Malik AS, Fogelsanger LN, Lewis S, Panikashvili D, Shohami E, Jansen SA, Narayan RK, Strauss KI: Cyclooxygenase-2-specific inhibitor improves functional outcomes, provides neuroprotection, and reduces inflammation in a rat model of traumatic brain injury. Neurosurgery 56:590-604, 2005

8. Hakan T, Toklu HZ, Biber N, Ozevren H, Solakoglu S, Demirturk P, Aker FV: Effect of COX-2 inhibitor meloxicam against traumatic brain injury-induced biochemical, histopathological changes and blood-brain barrier permeability. Neurol Res 32(6):629-635, 2010

9. Hausmann R, Biermann T, Wiest I, Tübel J, Betz P: Neuronal apoptosis following human brain injury. Int J Legal Med 118 : 32-36, 2004
10. Hickey RW, Adelson PD, Johnnides MJ, Davis DS, Yu Z, Rose ME, Chang YF, Graham SH: Cyclooxygenase-2 activity following traumatic brain injury in the developing rat. Pediatr Res 62: 271-276, 2007

11. Kelley BJ, Lifshitz J, Povlishock JT: Neuroinflammatory responses after experimental diffuse traumatic brain injury. J Neuropathol Exp Neurol 66:989-1001, 2007

12. Kontos HA, Dietrich WD, Wei EP, Ellis EF, Povlıshock JT: Abnormalities of the cerebral microcirculation after traumatic injury: The relationship of hypertension and prostaglandins. Adv Exp Med Biol 131:243-256, 1980

13. Kunz T, Marklund N, Hillered L, Oliw EH: Cyclooxygenase-2, prostaglandin synthases, and prostaglandin $\mathrm{H} 2$ metabolism in traumatic brain injury in the rat. J Neurotrauma 19: 1051-1064, 2002

14. Lenzlinger PM, Morganti-Kossmann MC, Laurer HL, Mclntosh TK: The duality of the inflammatory response to traumatic brain injury. Mol Neurobiol 24:169-181, 2001

15. Linnik MD, Miller JA, Sprinkle-Cavallo J, Mason PJ, Thompson FY, Montgomery LR, Schroeder KK: Apoptotic DNA fragmentation in the rat cerebral cortex induced by permanent middle cerebral artery occlusion. Brain Res Mol Brain Res 32(1):116-124, 1995

16. Liou AK, Clark RS, Henshall DC, Yin XM, Chen J: To die or not to die for neurons in ischemia, traumatic brain injury and epilepsy: A review on the stress-activated signaling pathways and apoptotic pathways. Prog Neurobiol 69:103-142, 2003

17. Lu J, Marmarou A, Choi S, Maas A, Murray G, Steyerberg EW: Impact and abic study group. Mortality from traumatic brain injury. Acta Neurochir Suppl 95:281-285, 2005

18. MacManus JP, Buchan AM, Hill IE, Rasquinha I, Preston E: Global ischemia can cause DNA fragmentation indicative of apoptosis in rat brain. Neurosci Lett 164(1-2):89-92, 1993

19. Marmarou A, Foda MA, van den Brink W, Campbell J, Kita $H$, Demetriadou K: A new model of diffuse brain injury in rats. Part I: Pathophysiology and biomechanics. J Neurosurg 80:291-300, 1994

20. McIntosh TK, Juhler M, Wieloch T: Novel pharmacological strategies in the treatment of experimental traumatic brain injury. J Neurotrauma 5:731-769, 1998

21. Nagata S, Golstein P: The Fas death factor. Science 267: 1449-1456, 1995

22. Ohkawa H, Ohishi N, Yagi K: Assay for lipid peroxides in animal tissues by thiobarbituric acid reaction. Anal Biochem 95: 351-358, 1979

23. Okura T, Gong L, Kamitani T, Wada T, Okura I, Wei CF, Chang $\mathrm{HM}$, Yeh ET: Protection against Fas/Apo-1- and tumor necrosis factor-mediated cell death by a novel protein, sentrin. J Immunol 157:4277-4281, 1996

24. Paglia DE, Walentine WN: Studies on the quantitative and qualitative characterisation of erythrocyte glutathione peroxidase. J Lab Clin Med 70:158-169, 1967

25. Pickard JD, Czosnyka M: Management of raised intracranial pressure. J Neurol Neurosurg Psychiatry 56:845-858, 1993 
26. Pratiko D, Reiss P, Tang LX, Sung S, Rokach J, Mclntosh TK: Local and systemic increase in lipid peroxidation after moderate experimental traumatic brain injury. J Neurochem 80:894-898, 2002

27. Radhofer-Welte S, Rabasseda X: Lornoxicam, a new potent NSAID with an improved tolerability profile. Drugs Today (Barc) 36(1):55-76, 2000

28. Sattler $M$, Liang $H$, Nettesheim $D$, Meadows RP, Harlan JE, Eberstadt M, Yoon HS, Shuker SB, Chang BS, Minn AJ, Thompson CB, Fesik SW: Structure of BCl-xL-Bak peptide complex: Recognition between regulators of apoptosis. Science 275: 983-986, 1997

29. Scali C, Giovannini MG, Prosperi C, Bellucci A, Pepeu G, Casamenti F: The selective cyclooxygenase-2 inhibitor rofecoxib suppresses brain inflammation and protects cholinergic neurons from excitotoxic degeneration in vivo. Neuroscience 117:909-919, 2003

30. Schwartzman RA, Cidlowski JA: Apoptosis: The biochemistry and molecular biology of programmed cell death. Endocr Rev 14:133-151, 1993

31. Slemmer JE, Shacka JJ, Sweeney MI, Weber JT: Antioxidants and free radical scavengers for the treatment of stroke, traumatic brain injury and aging. Curr Med Chem 15: 404-414, 2008
32. Stellar H: Mechanisms and genes of cellular suicide. Science 267: 1445-1449, 1995

33. Strauss Kl: Antiinflammatory and neuroprotective actions of COX-2 inhibitors in the injured brain. Brain Behav Immun 22:285-298, 2008

34. Strauss Kl, Barbe MF, Marshall RM, Raghupathi R, Mehta $S$, Narayan RK: Prolonged cyclooxygenase-2 induction in neurons and glia following traumatic brain injury in the rat. $J$ Neurotrauma 17(8):695-711, 2000

35. Sun Y, Oberley LW, Ying L: A simple method for clinical assay of superoxide dismutase. Clin Chem 34:497-500, 1988

36. Thornberry NA, Lazebnik Y: Caspases: Enemies within. Science 281:1312-1316, 1998

37. Topcu I, Vatansever S, Var A, Cavus Z, Cilaker S, Sakarya M: The effect of Misoprostol, a prostaglandin E1 analog, on apoptosis in ischemia-reperfusion-induced intestinal injury. Acta Histochem 109(4):322-329, 2007

38. Ustun ME, Gurbilek M, Ak A, Vatansev H, Duman A: Effects of magnesium sulfate on tissue lactate and malondialdehyde levels in experimental head trauma. Intensive Care Med 27:264-268, 2001

39. Vane JR, Botting RM: New insights into the mode of action of anti-inflammatory drugs. Inflamm Res 44:1-10, 1995 